\title{
IMPACT OF THE FDI ON UNEMPLOYMENT RATE IN COUNTRIES OF WEST BALKAN
}

\section{Dijana Grahovac, Senad Softić}

(1) Central Bank of Bosnia and Herzegovina, Bosnia and Herzegovina

(2) Central Bank of Bosnia and Herzegovina, Bosnia and Herzegovina

Dijana Grahovac

Central Bank of Bosnia and Herzegovina

Bosnia and Herzegovina

jonidg11@yahoo.com

Article info

Paper category: Original

Received: $14 \cdot 4 \cdot 2017$.

Accepted: 22.7.2017.

JEL classification: $\mathrm{G}_{10}, \mathrm{G}_{11}, \mathrm{G}_{2} 3$ 


\begin{abstract}
Modern economy is facing many challenges, in global terms. One of them is the high unemployment rate in many countries. That is a crucial problem, which jeopardises economic, social and political stability. Many factors have an impact to it, and some of them are globalisation, fast development of high technology, global economic crisis and expressed instability of financial markets. In addition, the relation of offer and demand is highly expressed in favour of the offer, the excess of capital at the global level is evident and seeks opportunities of investment as profitable as possible. The situation where the interests of big capital opposed to the costs is becoming more pronounced, which is reflected in the increasing growth of FDI in countries with lower operating costs. On the other hand, underdeveloped and developing countries spread the range of measures for attracting foreign direct investment (FDI), since it is one of the ways for increasing employment rate. This matter has already been the subject of numerous studies, particularly during the period of transition of countries in CEE. However, in modern frameworks, it is actualized again, with different circumstances and motives. In this article global unemployment rates, flows of FDI, their correlation in the Western Balkan countries and comparative analysis with chosen countries are presented. The period observed is 2000-2014. The paper is devoted to the influence of foreign direct investment on labour market. The interdependencies between FDI and unemployment were econometrical. The analysis showed that since 2009 , there is a significant reduction of net investments, which is more obvious in the case of FDI due to a lower domestic and external demand as a result of the global economic crisis what led to a decreasing number of employees and rising unemployment. Results, also, show the absence of a positive impact of FDI on employment, which was present in most CEE countries during the transition period, as shown in numerous empirical studies.
\end{abstract}

\title{
Keywords:
}

Foreign direct investment; Unemployment rate; Global economic crisis; the Western Balkans countries; Economic security 


\section{INTRODUCTION}

It is well known that the four major economic policy objectives are: full employment, price stability, high and sustainable rate of economic growth, and keeping the balance of payments in equilibrium (Benazić, Rami, 2016). Economic theory shows that unemployment, expression of existing imbalances in the economy, is due to multiple causes, both located at the macroeconomic level (e.g. lower effective demand, changing economic structure, asymmetry of the educational system to the labour market needs, fiscal policies that lead to increased fiscal pressure on employers, financial and monetary policies that discourage saving and investment and so on) and at the microeconomic level, resulting essentially in the individual decisions of entrepreneurs on restraining or restructuring of activity, assimilation of technological progress, sources of financing, wage policy, etc. as well as the supply of labour (skill level, adaptability and flexibility of people, individual aspirations and motivations and so on) (Angelescu et al., 2009). In essence, the literature distinguishes between structural and short term unemployment, voluntary and involuntary unemployment, cyclical and seasonal unemployment, etc. (Iacovoiu, 2012).

Numerous authors have studied in their empirical research realm of FDI, and their impact on the employment rate. In principle, all of them have accepted that positive employment effects are usually much higher if the FDI has the form of a Greenfield project. On the other hand when the foreign capital inflow takes the form of buyouts of privatised enterprises, it usually can have minor or even negative influence on employment (Hisarciklilar et all, 2009). Studying comparatively the econometric research on the relationship between investment and employment based on the analysis of individual companies and plants, researchers Stephen Bond and John $\mathrm{V}$. Reenen underlined the increasing importance of multinational companies, concluding the following (Bond, S., Reenen, J.V.,2003): 1. Multinational corporations now account for a significant and growing share of total domestic investment and employment in many countries and 2. Their investment and employment behaviour qualitatively differ from that of purely domestic firms. Positive influence of FDI on employment growth in case of developing countries was found in China. As one of the world's most important recipients of FDI, Chinese labour market has significantly benefited from foreign capital inflow. Karlsson et all analyse FDI inflow and employment growth in China based on firm level evidence, using a large sample of manufacturing firms for the period 1998- 2004. That research shows that FDI have positive effects on employment, which is result of job creation within foreign firms as well as indirect effect of FDI on employment in domestic firms. These researches argue that the high employment growth in foreign firms operating in China is associated with their specific characteristics such as high productivity, capital intensity and their high survival rate. Employment growth is also relatively high in private domestic Chinese firms. In this research both foreign companies and private domestic 
firms have relatively high employment growth, as compared to non-private domestic firms. The authors attribute the positive indirect effect of FDI on employment in private domestically-owned firms to positive spill-over effects from FDI (Karlsson et all, 2009). In the case of FDI inflows into GEE, primary motivations for expansion of multinational companies in Central and Eastern Europe (CEE) are market size and low cost production factors (Manea, Pearce, 2004). In case of Polish economy Stawicka investigated the relations between FDI and the situation of labour market. This research was showing some positive implications of foreign capital for labour markets, but the final results were inconclusive. However, this analysis was not based on econometric evaluation (Stawicka, 2009). Balcerzak and Zurek in their empirical research suggest that inflows of foreign direct investment has an impact on unemployment in Poland, while the level of unemployment rate influences on the gross domestic product (Balcerzak and Zurek, 2011). The results of causality tests based on data of $8 \mathrm{EU}$ candidate countries for the period 1994-2001 have suggested that the impact of FDI inflows on economic growth has been negative (Mencinger, 2003). The author attributes this negative effect of FDI to the observation that FDI in these countries have largely taken the form of acquisition of fixed assets owned by public and the proceeds of the sales of these assets were used to finance additional consumption instead of productive investment leading to increase in imports and current account deficits. Stamatiou and Dritsakis (2014) are using several econometric models to evaluate the impact of the FDI on unemployment and economic growth in Greece. The analysis of equitation of FDI in the short run and in the long run shows that an increase of FDI will increase growth and will reduce unemployment. Global financial crisis of the years 2008-2010 has proved that under some unfavourable conditions capital flows and international financial interconnections between countries can lead to serious destabilization of their real economies (Thalassinos, 2008). On the other hand, globalization and the availability of international capital can be a source of great opportunity for developing countries (Balcerzak, Zurek, 2011). According to the results of the regression our hypothesis that FDI have positive impact and are statistically important for decrease the unemployment in the Republic of Macedonia cannot be confirmed (Djambaska, 2015). The impact of FDI to unemployment is not statistically significant. It means that, unemployment is more influenced by other factors.

\section{GLOBAL VIEW OF UNEMPLOYMENT RATE AND INFLOW OF FDI}

The classical theory, as analysed by Pigou (1933) and Solow (1981), argues that the labour market consists of demand and supply of labour. Demand for labour is a derived demand, obtained from the declining portion of the marginal product of labour. The demand curve is a negative function of real wage in that 
if wages increase the quantity demand for labour will decline and the opposite is correct. The supply of labour is derived from worker's choice whether to spend part of time working or not working (leisure). Supply of hours worked is a positive function of the real wage, because if the real wage rises, workers supply more hours of work. In equilibrium, demand and supply of labour are intersected at a clearing point that determines the equilibrium real wage rate and full employment. Unemployment, (Sweezy, 194,0) explaining Pigou's Theory of Unemployment, "apart from frictional obstructions...would be non-existent if it were not for the fact that wage-earners habitually stipulate for a rate of wages higher than the 'equilibrium' level." Wicksell thinks that if wages are sufficiently flexible downward, then this decline can maintain full employment (Jonung, 1989). Essentially, for Wicksell the cyclical unemployment was due to the wrong investment of capital. Hayek (Nishhiyama, Leube, 1984) contends that unemployment is due "to a discrepancy between the distribution of labour...between industries... and the distribution of demand among their producers. This discrepancy is caused by a distortion of the system of relative prices and wages." Recently, the unemployment problem has been attributed to the globalization process. For example, shifting production and outsourcing to other countries have generated a high rate of structural unemployment in the U.S. economy, which has contributed for the increase in the rate of unemployment.

As growth slows in emerging and developing economies, social unrest has been on the rise. After a few turbulent years in the aftermath of the global crisis, the expression of dissatisfaction with the economic and social situation had started to decline in many regions (ILO, 2015), but as the economic situation began to deteriorate once more, most notably in developing economies, social unrest became more apparent. When there is a shortage of decent jobs, more workers may give up looking for work. In 2015, the number of working-age individuals who did not participate in the labour market increased by some 26 million to reach over 2 billion. Participation rates are expected to stabilize at 62.8 per cent of the global working-age population (aged 15 years and above) but then to follow a moderate downward trend, reaching 62.6 per cent in 2020 and falling further in subsequent years.

Table 1. provides an overview of trends in the unemployment rate in selected countries in the period 2000-2014. Consistently low unemployment rate can be seen in Switzerland, followed by China and Japan. All three countries had, over the entire period, an unemployment rate below the average unemployment rate at the global level. On the other side are the EU countries, high income countries and countries of Sub-Saharan region, which are permanently above the global average. In the case of the USA, there are two periods to be observed - one before and the other after the onset of the global economic crisis. In the period before the crisis, the unemployment rate was at a low level, below the global average, while in 2010 it reached a rate of 9.70 which makes a1 $37 \%$ increase. 
Table 1.: Unemployment rate in chosen countries, in the period from 2000 to 2014 .

\begin{tabular}{|c|c|c|c|c|c|c|c|}
\hline 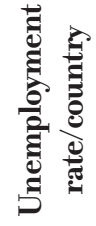 & 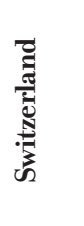 & :ีّ & $\begin{array}{l}\text { స్ } \\
\text { స్ }\end{array}$ & 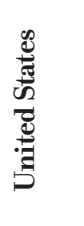 & 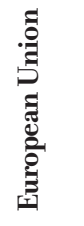 & 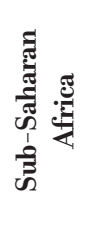 & 흄 \\
\hline 2000 & 2,70 & $4,5^{\circ}$ & $4,8 \circ$ & 4,10 & 9,20 & 9,10 & $6,4,0$ \\
\hline 2001 & $2,5^{\circ}$ & $4,5^{\circ}$ & 5,00 & 4,80 & 8,70 & 9,०० & $6,4,0$ \\
\hline 2002 & 2,90 & $4,4,0$ & 5,40 & 5,90 & 9,00 & 8,90 & $6,5^{\circ}$ \\
\hline 2003 & 4,10 & $4,3 \circ$ & 5,20 & 6,10 & $9, \infty \circ$ & $8,7 \circ$ & 6,50 \\
\hline 2004 & $4,3 \circ$ & $4,3 \circ$ & 4,70 & 5,60 & 9,20 & $8,4,0$ & $6,3 \circ$ \\
\hline 2005 & $4,4 \circ$ & 4,10 & 4,40 & 5,20 & 9,00 & 8,10 & 6,20 \\
\hline 2006 & $4, \infty \circ$ & 4,00 & 4,10 & $4,7 \circ$ & 8,20 & 8,20 & $5,9 \circ$ \\
\hline 2007 & 3,60 & $3,8 \circ$ & 3,90 & 4,70 & 7,20 & 7,90 & $5,5^{\circ}$ \\
\hline 2008 & 3,40 & $4,4,0$ & $4, \infty$ & 5,90 & 7,00 & 8,10 & $5,7 \circ$ \\
\hline 2009 & 4,10 & 4,40 & 5,00 & 9,40 & 9,00 & 8,10 & 6,20 \\
\hline 2010 & $4,5^{\circ}$ & 4,20 & 5,00 & 9,70 & 9,60 & 8,10 & 6,10 \\
\hline 2011 & $4, \infty \circ$ & $4,3 \circ$ & $4,5^{\circ}$ & 9,00 & 9,60 & 8,10 & 6,00 \\
\hline 2012 & 4,20 & $4,5^{\circ}$ & $4,3 \circ$ & 8,20 & $10,5^{\circ}$ & 8,10 & 6,00 \\
\hline 2013 & 4,40 & $4,6 \circ$ & $4, \infty$ & 7,40 & 10,90 & 7,90 & $6, \infty \circ$ \\
\hline 2014 & $4,5^{\circ}$ & $4,7 \circ$ & 3,70 & 6,20 & 10,20 & 8,०० & 5,90 \\
\hline
\end{tabular}

Source: World Bank, Indicators

As it is mentioned, the influence of FDI on labour market conditions has been extensively studied in recent years. It is commonly stated that FDI usually bring strong positive results for labour market of a beneficiary as it results in decreasing the level of unemployment. As a result, in case of political process and political decision making this argument is very often used as justification for significant government direct financial support for international investors that plan their investments in a given country. Transnational corporation often directly influence government policy to lobby for a more favourable policy mix in the area of regulations, taxation or other form of direct and indirect support by utilizing their influence as potential large employers (Whyman, 2006).

Table 2. showed inflow of FDI in chosen countries, in the period from 2000 to 2014. In the first place, according to the inflow of FDI, is the EU, with $42 \%$ compared to the global level of FDI inflows. It is followed by USA and Japan, at a much lower level. This suggests a conclusion that in the EU there has not been significant deindustrialization to countries with lower costs. The data indicate the disparity in the 
inflow of FDI, as the first 5 countries (excluded region Sub-Saharan Africa) make up $67 \%$ of the global inflow of FDI. Underdeveloped and developing countries still do not have an attractive investment environment.

Table 2.: Foreign direct investments, net inflows in chosen countries, in the period from 2000 to 2014, mil.USD

\begin{tabular}{|c|c|c|c|c|c|c|c|}
\hline 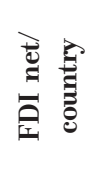 & 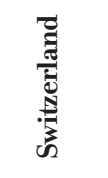 & 莽 & సี & 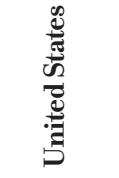 & 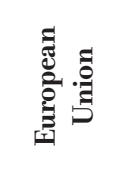 & 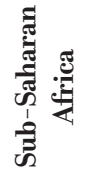 & ?: \\
\hline 2000 & 23080 & 42095 & 10688 & 350066 & 709129 & 6873 & 146063 \\
\hline 2001 & 9765 & $477^{\circ} 5^{3}$ & 4926 & $17147^{1}$ & $33415^{3}$ & 15418 & 796076 \\
\hline 2002 & $825^{8}$ & $5^{3 \circ} 74$ & 11557 & 109466 & 382745 & 10836 & $7415^{32}$ \\
\hline 2003 & 19721 & 57901 & $877^{1}$ & 111346 & 32908 & 13817 & 709827 \\
\hline 2004 & $7^{102}$ & 68117 & $75^{28}$ & 207877 & 395975 & 12293 & 1004236 \\
\hline 2005 & 2665 & 104,108 & 5460 & 138327 & $94647^{6}$ & $195^{8} 4$ & 1522213 \\
\hline 2006 & $5^{3} 760$ & 133272 & -2397 & 294288 & 1095616 & 16415 & 2136124 \\
\hline 2007 & 48688 & 156249 & 21631 & 340065 & 1663711 & 29965 & $3065^{3} 5^{3}$ \\
\hline 2008 & 2991 & $1715^{3} 5$ & 24,625 & $3327^{3} 34$ & 1077110 & 38914 & 244,3685 \\
\hline 2009 & $47^{6} 5^{8}$ & 131057 & 12226 & $15^{3} 7^{88}$ & $445^{3} 47$ & $365^{81}$ & $136 \circ 7^{36}$ \\
\hline 2010 & 17670 & 243703 & $7440^{\circ}$ & $259^{3} 44$ & 577509 & 28283 & $185^{8942}$ \\
\hline 2011 & 23198 & 280072 & $-85^{\circ}$ & $25741^{1}$ & 851104 & 4.0646 & 2285754 \\
\hline 2012 & 26288 & 24,1214 & 546 & 24,3011 & 733227 & 36629 & $211088 \circ$ \\
\hline 2013 & $-24,898$ & 290928 & 10648 & $27697^{8}$ & $605^{892}$ & $3847^{1}$ & 2086334 \\
\hline 2014 & 18375 & 268097 & 184.09 & 207367 & 391497 & 44439 & 1780093 \\
\hline Total & 284,321 & 2288475 & 14,1208 & 3221869 & 10242399 & 389164 & $24,047^{8} 48$ \\
\hline
\end{tabular}

Source: World Bank, Indicators

Note: Foreign direct investment refers to direct investment equity flows in the reporting economy. It is the sum of equity capital, reinvestment of earnings, and other capital. Direct investment is a category of cross-border investment associated with a resident in one economy having control or a significant degree of influence on the management of an enterprise that is resident in another economy. Ownership of 10 per cent or more of the ordinary shares of voting stock is the criterion for determining the existence of a direct investment relationship. Data are in current U.S. dollars.

\subsection{Unemployment rate and inflow of FDI in the Western Balkan countries}

The Western Balkan countries, like others countries in transition, have permanently high unemployment rate. Such a situation is further aggravated by the influence 
of the global economic crisis. The lowest unemployment rates were recorded in Croatia and Albania, while the highest were in B\&H and FYRM (Former Yugoslav Republic of Macedonia). Serbia and Montenegro are in the middle of the scale. What is of concern is the constantly high unemployment rate in all countries, with the exception of Croatia in 2007-2011, that significantly deviate from the global average (as shown in the next table).

Table 3.: Unemployment rate in The Western Balkan countries, in the period from 2000 to 2014.

\begin{tabular}{|c|c|c|c|c|c|c|}
\hline 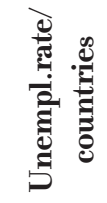 & 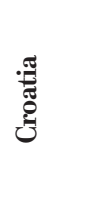 & 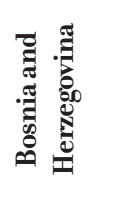 & $\begin{array}{l}\text { 卺 } \\
\text { है }\end{array}$ & 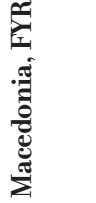 & مُّ & 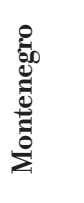 \\
\hline 2000 & 16,10 & 25,20 & 13,50 & 32,20 & 12,60 & 19,70 \\
\hline 2001 & 20,50 & 27,60 & 22,70 & 30,50 & 12,80 & 21,00 \\
\hline 2002 & 15,10 & 24,60 & $13,4,0$ & 31,90 & 13,80 & 21,00 \\
\hline 2003 & 13,90 & 26,00 & $12,7^{\circ}$ & 36,70 & 15,20 & 21,10 \\
\hline 2004 & 13,70 & 28,30 & 12,60 & 37,20 & $18,5^{\circ}$ & 19,30 \\
\hline 2005 & 12,60 & 26,00 & $12,5^{\circ}$ & $37,3 \circ$ & 20,80 & $19,5^{\circ}$ \\
\hline 2006 & 11,10 & 31,80 & $12,4,0$ & 36,00 & 20,80 & 18,20 \\
\hline 2007 & 9,60 & 29,70 & $13,5^{\circ}$ & 34,90 & 18,10 & 19,40 \\
\hline 2008 & 8,40 & 23,90 & $13, \infty 0$ & 33,80 & 13,60 & 16,80 \\
\hline 2009 & 9,10 & 24,10 & 13,80 & 32,20 & 16,60 & 19,10 \\
\hline 2010 & 11,80 & 27,20 & 14,20 & 32,00 & 19,20 & 19,70 \\
\hline 2011 & 13,40 & 27,60 & $14, \infty 0$ & 31,40 & 23,00 & 19,70 \\
\hline 2012 & 15,80 & 28,10 & 13,90 & 31,00 & 23,90 & 19,60 \\
\hline 2013 & $17,3 \circ$ & 27,40 & $16, \infty 0$ & $29, \infty 0$ & 22,10 & $19,5^{\circ}$ \\
\hline 2014 & 16,70 & 27,90 & 16,10 & 27,90 & 22,20 & 19,10 \\
\hline
\end{tabular}

Source: World Bank, Indicators

Table 4. shows the inflow of FDI in WB countries. Evident is a very small amount, which, for the whole region, makes only $9 \%$ of the inflow of FDI in the EU. The first is Croatia, followed by Serbia, while other countries have significantly lower levels of FDI inflows. All countries observed intensify their efforts to create an attractive investment environment, but without effective results. Although a free trade zone CEFTA was formed in 2006, inter alia, so as to strengthen the investment environment at the regional level, the Member States pose themselves as competitors rather than partners in the process of attracting FDI. Also, Croatia entered the EU in mid2013 and it has given some stability to the inflow of FDI, which is absent. 
Table 4.: Foreign direct investments, net inflows in chosen countries, in the period from 2000 to 2014 , mil.USD

\begin{tabular}{|c|c|c|c|c|c|c|}
\hline & 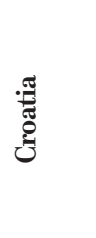 & 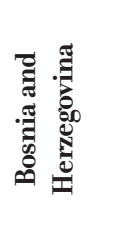 & 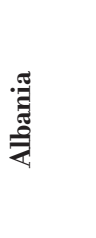 & 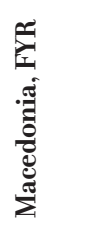 & 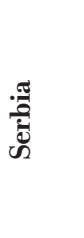 & 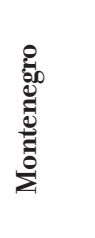 \\
\hline 2000 & $105^{6}$ & 146 & 143 & 217 & $5^{2}$ & \\
\hline 2001 & $9^{8} 4$ & 118 & 207 & $47^{\circ}$ & 177 & \\
\hline 2002 & $95^{3}$ & 268 & ${ }_{13} 3$ & 114 & $49^{1}$ & 72 \\
\hline 2003 & 1826 & 382 & $17^{8}$ & 119 & 1467 & 49 \\
\hline 2004 & 1293 & 890 & 34,1 & 309 & $95^{8}$ & 65 \\
\hline 2005 & 1794 & 624 & 262 & 145 & 1577 & $5^{01}$ \\
\hline 2006 & 3299 & 846 & 325 & 427 & 4256 & 622 \\
\hline 2007 & 4567 & 1842 & $65^{2}$ & $7^{3} 3$ & 4424 & 937 \\
\hline 2008 & $5^{188}$ & 1005 & 124.1 & 612 & $405^{6}$ & 975 \\
\hline 2009 & 3199 & 138 & 1343 & 259 & 2929 & 1549 \\
\hline 2010 & 1424 & 444 & 1089 & 301 & 1693 & $75^{8}$ \\
\hline 2011 & 14,18 & 472 & 1049 & 508 & $493 \circ$ & $55^{6}$ \\
\hline 2012 & 14,65 & 392 & 920 & 338 & 1276 & 618 \\
\hline 2013 & 937 & 313 & 1254 & 4,02 & 2060 & 446 \\
\hline 2014 & 3960 & $5^{23}$ & 1149 & 61 & 1999 & 497 \\
\hline Total & 33363 & 84,03 & 10288 & 5015 & 32345 & 7645 \\
\hline
\end{tabular}

Source: World Bank, Indicators

\section{ECONOMETRIC ANALYSES}

Multiple Linear Regression (R) is used to find out the relationship between FDI and unemployment rate. The formula applied is:

$$
\ln U R_{t}=\beta_{0}+\beta_{1} \ln F D I_{t}+\varepsilon_{t}
$$

where

$\beta_{0}=$ Intercept

$\beta_{1}=$ slope (measure the impact of the dependent variable on the independent variable) $F D I_{t}=$ Foreign Direct Investment in period $t$

$U R_{t}=$ Unemployment Rate in period $t$

$\varepsilon_{\mathrm{t}}=$ Random Error. 
Before fitting our regression model we want to investigate how the variables are related one to another. It can be done graphically by constructing scatter plots of all pair-wise combinations of variables in the data frame.

The null hypothesis is the existence of a link of impact of FDI inflows to reduction of the unemployment rate. The null hypothesis is rejected if the F calculated from the data is greater than the critical value of the F-distribution for some desired false-rejection probability (e.g. 0.05 ). To determine whether a result is statistically significant, a researcher calculates a p-value, which is the probability of observing an effect given that the null hypothesis is true (Devore, 2011). The null hypothesis is rejected if the $\mathrm{p}$-value is less than a predetermined level. Sig. is called the significance level, and is the probability of rejecting the null hypothesis given that it is true (a type I error). It is usually set at or below $5 \%$.

From the figures (Figure 1. - Figure 8.) Normal Probability Plots, a significant deviation can be seen in the case of Albania (Figure 3.), and then of Croatia (Figure 5.), thus indicating the existence of other factors which influence the labour market. Other countries show dispersion around a straight line or a slight deviation.

Figure 1.: Normal P-P Plot of regression, in case of EU

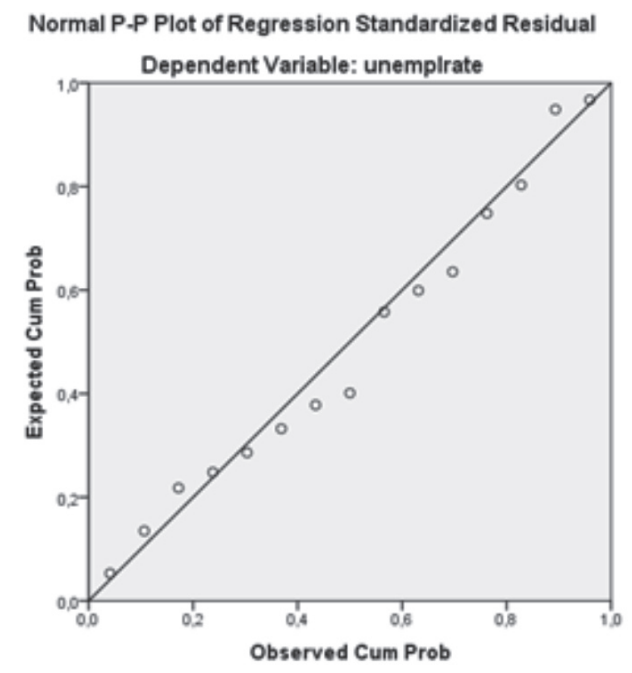

Source: Authors' 
Figure 2.: Normal P-P Plot of regression, in case of World

\section{Normal P.P Plot of Regression Standardized Residual}

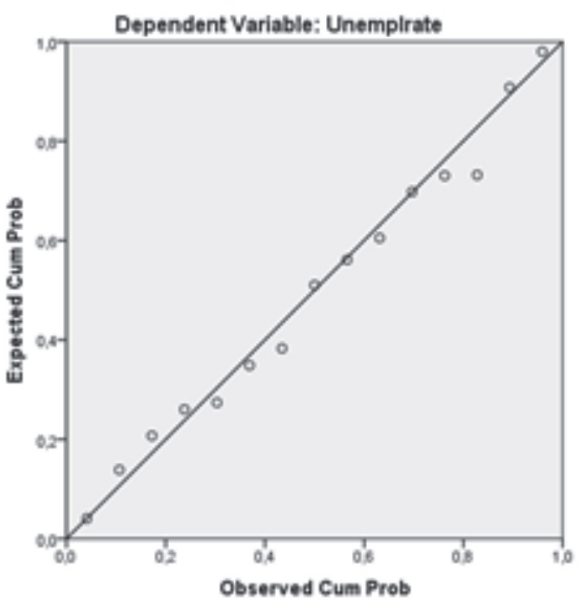

Source: Authors'

Figure 3.: Normal P-P Plot of regression, in case of Albania

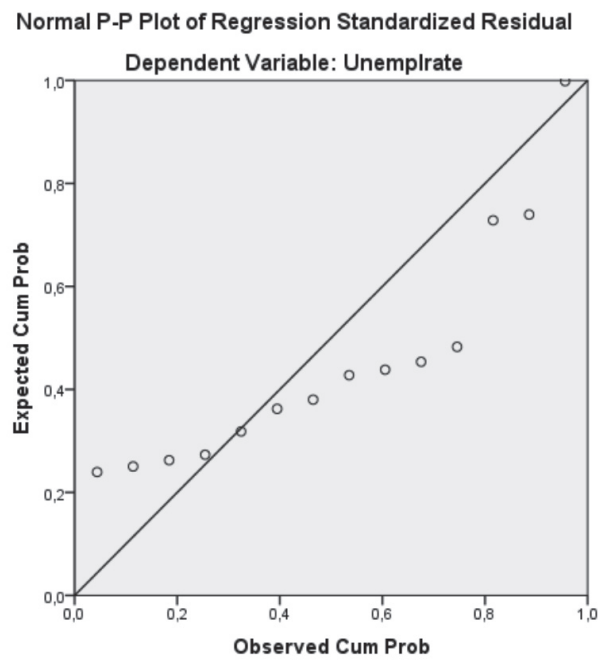

Source: Authors' 
Figure 4.: Normal P-P Plot of regression, in case of B\&H

\section{Normal P-P Plot of Regression Standardized Residual}

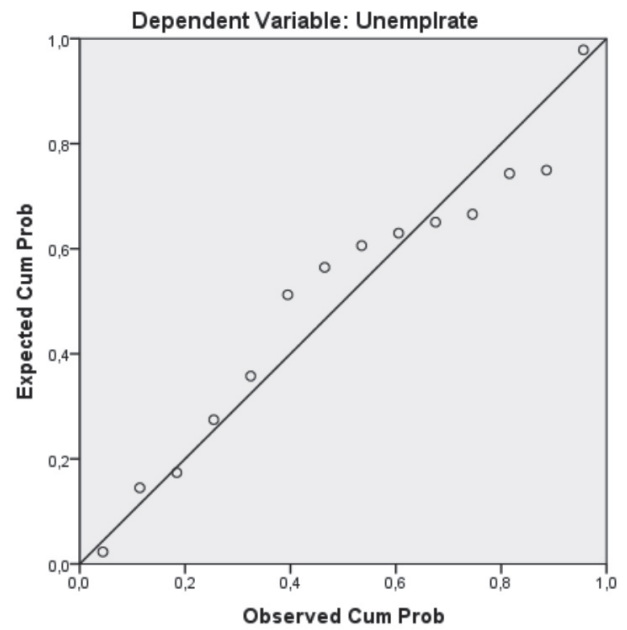

Source: Authors'

Figure 5.: Normal P-P Plot of regression, in case of Croatia

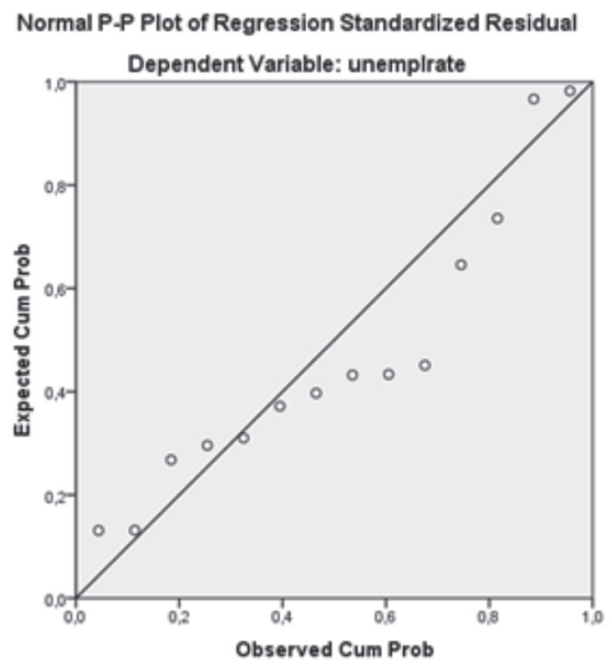

Source: Authors' 
Figure 6.: Normal P-P Plot of regression, in case of FYRM

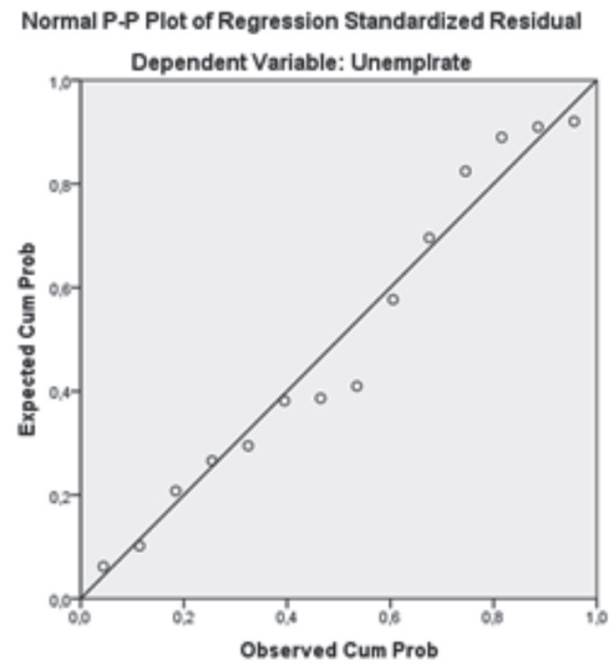

Source: Authors'

Figure 7.: Normal P-P Plot of regression, in case of Montenegro

\section{Normal P.P Plot of Regression Standardized Residual}

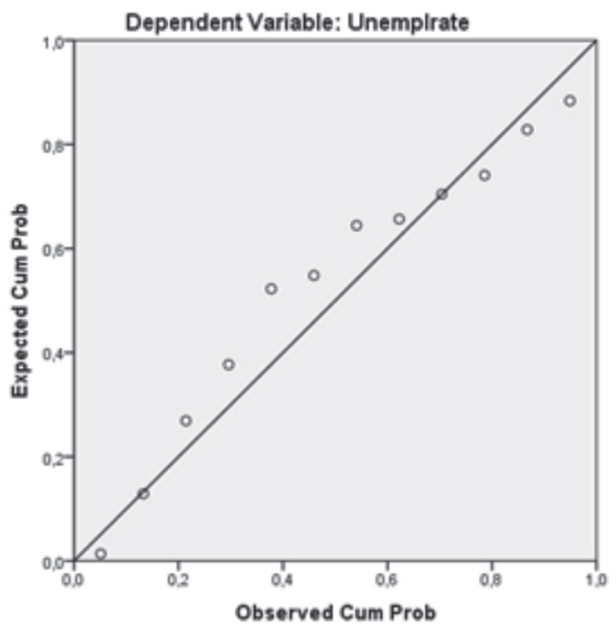

Source: Authors' 
Figure 8.: Normal P-P Plot of regression, in case of Serbia

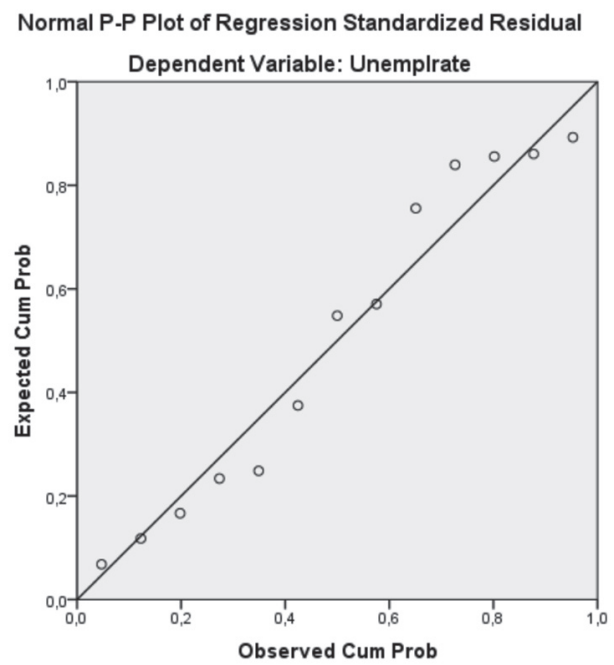

Source: Authors'

Table 5 . shows the results of a regression analysis, wherein:

- $\mathrm{R}$ - called the linear correlation coefficient, measures the strength and the direction of a linear relationship between two variables. It can have the following values $-1<R<1$. The mathematical formula for computing $R$ is:

$$
r=\frac{1}{n-1} \Sigma\left(\frac{x-\bar{x}}{s_{x}}\right)\left(\frac{y-\bar{y}}{s_{y}}\right)
$$

- $\mathrm{R}^{2}$ is the coefficient of determination, is useful because it gives the proportion of the variance (fluctuation) of one variable that is predictable from the other variable. It is a measure that allows us to determine how certain one can be in making predictions from a certain model/graph. The coefficient of determination is the ratio of the explained variation to the total variation. The coefficient of determination is such that $0<R^{2}<1$, and denotes the strength of the linear association between $\mathrm{x}$ and $\mathrm{y}$. The coefficient of determination represents the percentage of the data that is the closest to the line of best fit. For example, if $\mathrm{R}=0.922$, then $\mathrm{R}^{2}=0.85$, which means that $85 \%$ of the total variation in $\mathrm{y}$ can be explained by the linear relationship between $\mathrm{x}$ and $\mathrm{y}$ (as described by the regression equation). The other $15 \%$ of the total variation in y remains unexplained.

- The adjusted R-squared compares the descriptive power of regression models that include diverse numbers of predictors. Every predictor added to a model increases R-squared and never decreases it. Thus, a model with more terms may seem to have a better fit just for the fact that it has more terms, while the adjusted R-squared compensates for the addition of variables and only in- 
creases if the new term enhances the model above what would be obtained by probability and decreases when a predictor enhances the model less than what is predicted by chance. In an over-fitting condition, an incorrectly high value of $\mathrm{R}$-squared, which leads to a decreased ability to predict, is obtained. This is not the case with the adjusted R-squared.

- The threshold of significance is the condition Sig. < ०,०5

- The coefficient $\mathrm{R}$ (beta) is preferably as large as possible in the negative direction, i.e. that the relationship between FDI inflow and the unemployment rate is inversely proportional. This is evident at the global level (coefficient is negative and very high - - 0.95), indicating a very strong relation of impact of FDI inflows to reduction of the unemployment rate. This result further confirmed R Square, Adjusted R Square and the level of significance $(0, \infty)$. In the case of the EU, there is also a negative coefficient, in the range of significant influence relation, with somewhat lower other indicators and satisfaction of conditions of significance level. When it comes to the WB countries, the significance condition is only met by Croatia with the R coefficient of - 0.645 , which indicates the significant impact of FDI inflows to unemployment reduction. Albania has a negative $\mathrm{R}$ coefficient, as well as drastic departure from the threshold of significance, suggesting that other factors influence the labour market. Montenegro has good indicators, but does not meet the level of significance. In case of FYRM there is no reported relation of influence, as evidenced by the significant deviation from the threshold of significance, while the situation is very similar when speaking about Serbia. The coefficient of $0,4,13$ at B\&H shows the impact of an increase in the FDI inflow to the increase in the unemployment rate. One of the factors for this situation is inefficient privatization, thus privatising some large companies through FDI, which then fired employees of even been liquidated.

Table 5.: Result of multiple linear regression

\begin{tabular}{|l|r|r|r|r|}
\hline \multicolumn{1}{|c|}{ Indicator/country } & R (beta) & \multicolumn{1}{c|}{ R Square } & \multicolumn{1}{c|}{$\begin{array}{c}\text { Adjusted R } \\
\text { Square }\end{array}$} & \multicolumn{1}{c|}{ Sig. } \\
\hline Albania & $-0,10$ &, 000 &,- 083 &, 972 \\
B\&H &, 413 &, 170 &, 101 &, 142 \\
Croatia &,- 645 &, 416 &, 368 &, 013 \\
Serbia &, 197 &, 039 &,- 049 &, 519 \\
Montenegro &,- 454 &, 206 &, 126 &, 139 \\
FYRM &, 048 &, 002 &,- 081 &, 869 \\
World &,- 946 &, 895 &, 886 &, 000 \\
EU &,- 583 &, 340 &, 289 &, 023 \\
\hline
\end{tabular}

Source: Authors' calculation 


\section{CONCLUSION}

One of the key challenges of most modern countries is high unemployment rate, which creates social, economic and political pressure on the creators of economic policies. EU countries have not yet economically recovered from the devastating effects of the global economic crisis and the economies of member countries are still in the phase of recovery or stagnation. Such a situation in the EU is transmitted to the WB countries, which are intensively associated with the EU. The results of the empirical analysis of the impact of FDI on the unemployment rate indicate significant deviations of influence in the WB countries in relation to the global and EU level. The conclusion is that no country of WB is effectively implement structural reforms and the privatization process has not made the required results. In all the above countries is a small number of successful privatized enterprises, especially large enterprises of strategic significance, which are, by definition, has a large number of employees. Economic uncertainty is very strong in all countries and leads to political instability, as well as the expressed rates of youth migration to EU countries. Only Croatia shows a positive impact of FDI on the unemployment rate, but this rate is still high. In the case of other countries, there is the conclusion of the inadequacy of the FDI inflow structure and also the significant presence of other factors influencing the labour market in the countries studied. Given the persistent lack of capital and very high unemployment, all countries will, in future, need to find models of economic policies that will work towards increase of FDI inflows and reduction of the unemployment rate, so as to achieve economic, political, and social security. In modern conditions expressed financial instability and continuous large supply of favourable investment environment on a global scale, this process is not simple and requires raising the level of competitiveness at a significantly higher level. 


\section{REFERENCES}

Angelescu,C.(coord.), Dinu, M. (coord.), Gavrila, I.(coord.) and Popescu, C.(coord.),. Economie, Editura Economica, Bucuresti., (2009): 4,06-4.07

Benazić, Manuel, and Jasmin Rami. "Monetary policy and unemployment in Croatia." Economic ResearchEkonomska Istraživanja 29, no. 1 (2016): 1038-1049

Bond, Stephen, and John Van Reenen. "Microeconometric models of investment and employment." Handbook of econometrics 6 (2007): 4417-4498

Manea, Julia, and Robert Pearce. "Industrial restructuring in economies in transition and TNCs' investment motivations." Transnational Corporations 13, no. 2 (2004): 7-28

Hisarciklilar, Mehtap, Derya Gultekin-Karakas, and Ahmet Atil Asici. "Can FDI be a Panacea for Unemployment?: The Turkish Case." In Labor and employment relations in a globalized world, pp. 43-70. Springer International Publishing, 2014. Available at http://www.esam.itu.edu.tr/ NottinghamWorkshopPapers/Hisarciklilar-Karakas-Asici-NW.pdf.

Karlsson, Sune, Nannan Lundin, Fredrik Sjöholm, and Ping He. "Foreign firms and Chinese employment." The World Economy 32, no. 1 (2009): 178-201

Balcerzak, Adam P., and Miroslawa Zurek. "Foreign direct investment and unemployment: VAR analysis for Poland in the years 1995-2009." European Research Studies 14, no. 1 (2011): 3

Thalassinos, Eleftherios. "Trends and Developments in the European Financial Sector." European Financial and Accounting Journal 3, no. 3 (2008): 44-61

Balcerzak, Adam P., and Miroslawa Zurek. "Foreign direct investment and unemployment: VAR analysis for Poland in the years 1995-2009." European Research Studies 14, no. 1 (2011): 3

Mencinger, Jože. "Does foreign direct investment always enhance economic growth?." Kyklos 56, no. 4 (2003): 491-508

Whyman, Philip, and Mark Baimbridge. Labour market flexibility and foreign direct investment. DTI, 2006 .

Stamatiou, Pavlos, and Nikolaos Dritsakis. "The Impact of Foreign Direct Investment on the Unemployment Rate and Economic Growth in Greece: A Time Series Analysis." In International Work-Conference on Time Series Analysis (ITISE), vol. 1, pp. 97-108. 2014.

Djambaska, E., Foreign direct investment and unemployment evidence from the Republic of Macedonia. International Journal of Economics, Commerce and Management. United Kingdom, Vol. III, Issue 12. 2015 .

Jonung, Lars. "Knut Wicksell on unemployment." History of Political Economy 21, no. 1 (1989): 27-42

Nishiyama, C., and K. Leube. "The Essence of Hayek. Hoover Institution: Stanford University.", 1984.

Sweezy, Paul M. "Professor Pigou's theory of unemployment." Journal of Political Economy 42, no. 6 (1934): $800-811$

Devore, Jay L. Probability and Statistics for Engineering and the Sciences. Cengage learning, 2011. 
